\title{
Jak analizować podręczniki do nauki języków obcych? Garść uwag po lekturze książki Karen Risager Representations of the World in Language Tertbooks (Bristol 2018, 252 s.)
}

\author{
How to Analyze Foreign Language Tertbooks? \\ A Handful of Comments after Reading the Book of \\ Karen Risager Representations of the World in Language \\ Tertbooks (Bristol 2018, 252 pp.)
}

Polskie badania historycznojęzykowe obfitują w publikacje ukazujące mnogość i zróżnicowanie funkcjonalne tekstów, które tworzyli nasi językowi przodkowie. Wielu historyków języka skupia się na dziejach używania polszczyzny, opisując jej formy tekstowe, gatunkowe, dyskursowe oraz aspekt komunikacyjny języka'. Wśród przyrastających w szybkim tempie analiz tekstowych pozostałości życia społecznego, kulturowego i (rzadziej ostatnio eksplorowanego) artystycznego zaznacza się także grupa publikacji, które w centrum zainteresowania stawiają teksty związane z polonistyczną ${ }^{2}$ i glottodydaktyczną edukacją językową dawnych pokoleń (np. Rypel, 2012; Przyklenk, 2014; 2016; Kotlarska, 2017a, b). Najczęściej analizowanym typem tekstów są podręczniki używane w różnych organizacyjnie formach edukacji.

Swoisty „urok” podręczników jako przedmiotu językoznawczego oglądu leży w sposobie ich postrzegania przez użytkowników: zwykle uznaje się je za niezawodne i neutralne źródło obowiązującej wiedzy, o czym decyduje autorytet autorów, cytowanych ekspertów oraz wydawców. Prezentowana w nich wiedza podsuwa sposób pojmowania faktów i zjawisk umożliwiający odbiorcom uczestnictwo w życiu publicznym. Podręczniki do nauki języków nowożytnych są także świadectwem polsko-obcych kontaktów językowych, które $w$ roz-

* e-mail: i.kotlarska@ifp.uz.zgora.pl

1 O wybranych problemach podejmowanych przez polskich historyków języka, którzy koncentrują się na sposobie używania polszczyzny, pisał Artur Rejter w artykule Historyk języka jako tropiciel śladów (REJTER, 2018). Tekst opatrzony jest obszerną bibliografią opracowań historycznojęzykowych, w których istotną rolę odgrywają spostrzeżenia dotyczące wspólnoty komunikatywnej oraz okoliczności kulturowych, społecznych, historycznych, w jakich posługiwała się ona polszczyzną.

2 Rozkwit przeżywają badania dotyczące nauczania języka polskiego jako obcego w aspekcie historycznym. Tematem tym zajmowały się przede wszystkim Anna Dąbrowska oraz Anna Burzyńska-Kamieniecka, które przedmiotem analiz uczyniły dawne podręczniki do nauki języka polskiego adresowane do odbiorców niemieckojęzycznych. Na fali zwiększonego zainteresowania uczeniem (się) polskiego jako obcego więcej pisze się o przygotowaniu i ewaluacji materiałów glottodydaktycznych, sytuacji nauczania języka polskiego $w$ różnych krajach i regionach świata, kwestii polityki językowej w zakresie promocji i nauczania polszczyzny w świecie (na podstawie: MıdunKA, 2018). 
maitych okolicznościach dziejowych skłaniały naszych przodków do uczenia się innych języków, a tym samym do przyswajania wiedzy na temat ich rodzimych użytkowników i krajów ich pochodzenia. To powoduje, że podręczniki (także te funkcjonujące w minionych wiekach) stają się przedmiotem analiz, w których pojęciem przewodnim jest dyskurs edukacyjny ${ }^{3}$. Kategoria dyskursu pozwala spojrzeć na nie wieloaspektowo: jako na narzędzia przekazywania wiedzy i umiejętności, ale także jako na instrumenty kształtowania wartości, postaw, idei i światopoglądów - teksty uwikłane w społeczno-polityczne i kulturowe konteksty sformalizowanego procesu kształcenia.

Bogactwo historycznego materiału tekstowego obejmującego szeroko pojętą glottodydaktykę zachęca do poszukiwań publikacji, które poddają podręczniki do nauki języków obcych szerokiemu oglądowi uwzględniającemu ideologiczny, kulturowy, instytucjonalny, tożsamościowy kontekst ich powstania i funkcjonowania w urozmaiconych formach edukacji. Mnogość publikacji tego rodzaju przynosi piśmiennictwo anglojęzyczne. Międzynarodowy status angielszczyzny i jej dominująca pozycja języka obowiązkowo nauczanego na różnych poziomach edukacji w większości krajów świata sprawia, że wiele pisze się o materiałach do nauki tego języka. Omawiane są zwykle podręczniki współczesne ${ }^{4}$, co nie musi być przeszkodą dla badaczy zainteresowanych materiałami edukacyjnymi tworzonymi w przeszłości. Za wyjaśnienie niech posłużą słowa Mirosławy Siuciak: „[...] o ile badacz synchronista unika historycznych odniesień czy wręcz ich nie zauważa, o tyle historyk języka, sam zanurzony we współczesności, zazwyczaj od tej właśnie perspektywy zaczyna ogląd materiału historycznego" (SıUсıAK, 2015: 224).

W kontekście wieloaspektowego postrzegania materiałów edukacyjnych interesująca wydaje się praca Karen Risager ${ }^{5}$ Representations of the World in Language Tertbooks, wydana $w$ roku 2018 nakładem wydawnictwa Multilingual Matters w Bristolu ${ }^{6}$. Autorka deklaruje, że chce przyczynić się do wzbogacenia refleksji dotyczących treści socjokulturowych zamieszczanych w podręcznikach do nauki języków obcych. Język traktuje jako integralną część szerszego kontekstu społeczno-kulturowego, co pozwala doszukiwać się zbieżności z nurtem badań zwanym na gruncie polskim lingwistyką kulturową, a w badaniach anglojęzycznych znanym pod nazwą intercultural communication. Risager podkreśla, że dotych-

${ }^{3}$ Węższe rozumienie tego pojęcia prezentują prace Teodozji Rittel (por. np. Rıttel, 1998), szersze Jolanty Nocoń (zob. np. Nocoń, 2013). Przegląd sposobów jego rozumienia przedstawia m.in. Marta SZYMAŃSKA (2016: 26-33).

${ }^{4}$ Znaną pracą dotyczącą nauczania języka angielskiego w przeszłości jest książka Anthony'ego Philipa Reida Howatta A History of English Language Teaching (HowAt, 1984) oraz redagowana przez niego seria Foundations of Foreign Language Teaching, w której drukowane są historyczne podręczniki do nauki języka angielskiego istotne z punktu widzenia przemian metodycznych.

${ }_{5}$ Karen Risager jest duńską badaczką pracującą na Uniwersytecie w Roskilde. Jej zainteresowania koncentrują się na socjolingwistyce i kulturoznawstwie: zajmuje się związkami języka z kulturą, edukacją językową w społecznościach wielojęzycznych, tożsamością kulturową w nauczaniu języków obcych. Interesują ją także różnice w sposobie uczenia języka w systemach edukacji krajowej i międzynarodowej.

${ }^{6}$ Książka ukazała się jako 34. pozycja w serii wydawniczej Languages for Intercultural Communication and Education [Języki w Komunikacji Międzykulturowej i Edukacji. Wszystkie tłumaczenia z angielskiego - I.K.]. 
czasowe obserwacje sposobów przedstawiania kultury i rozmaitych elementów życia społecznego w podręcznikach do nauki języków obcych były fragmentaryczne. Publikowano je $w$ rozproszonych opracowaniach, dotyczących zwykle materiałów do nauki jednego języka, dlatego badaczka stawia sobie cel szerszy i przedmiotem opracowania czyni podręczniki do nauki sześciu języków: angielskiego, niemieckiego, francuskiego, hiszpańskiego, duńskiego i esperanto ${ }^{7}$, adresowane do nastolatków (13-16 lat) lub dorosłych ${ }^{8}$, używane w kraju zamieszkania autorki (Dania). Języki zhierarchizowano zgodnie z kolejnością rozpoczynania ich nauki w duńskim systemie edukacyjnym: najpierw angielski, potem niemiecki, francuski, hiszpański. Na kolejnej pozycji autorka stawia duński - jego nauczanie jako języka obcego w Danii odbywa się poza regularnym systemem edukacyjnym; na ostatnim miejscu umieszcza esperanto, którego - jako tzw. języka planowego - nie uczy się w szkołach, nie jest on także związany z konkretną narodowością czy państwem. Kluczowym kryterium doboru podręczników była wyrażana przez autorów chęć poruszania tematów związanych z kulturą i społeczeństwem. Popularność materiałów (rozumiana jako częstotliwość używania ich w szkołach) nie była decydująca. Analizom poddano wszystkie komponenty tzw. kursów językowych: podręczniki dla uczniów, materiały dla nauczycieli oraz zasoby cyfrowe przypisane do danej publikacji.

Omawiana książka dzieli się na osiem rozdziałów. Rozdziały 1. i 2. - Representations of the World oraz Culture in Textbook Analyses around the World - mają charakter teoretyczny: opisują cel i podstawę materiałową analiz, przynoszą także fundamentalne dla części analitycznej ustalenia terminologiczne, z których najistotniejsze wydaje się wyjaśnienie wyrażenia representations of the world (reprezentacje świata). Rozdziały od 3. do 7. zawierają analizę tematów uznanych przez autorkę za najistotniejsze dla konstruowania wiedzy o świecie odbiorców. Rozdział 8. to podsumowanie i wnioski.

Risager zaznacza, że utożsamia reprezentacje świata z kluczową w edukacji wiedzą o świecie. Pojęcie wiedzy wiąże (za Michelem Foucaultem) z władzą: wiedza jest zawsze zanurzona $w$ dyskursie, prezentowana $z$ punktu widzenia osób z określonym doświadczeniem życiowym. Wpływają na nią: obowiązujący $w$ danym kraju program nauczania, związany z systemem kształcenia, firmy wydawnicze, a nawet emocje (np. w podręcznikach dla nastolatków dominują emocje pozytywne, takie jak ciekawość czy żądza przygód). Tytułowe reprezentacje (representations) to termin wywodzący się z brytyjskiej szkoły kulturoznawczej, oznaczający konstruowanie i przedstawianie rzeczywistości $w$ taki sposób, aby nadać jej znaczenie. Język jest traktowany jako jeden z systemów reprezentacji (zob. Czachur, red., 2017). Dla autorki istotne są te reprezentacje kulturowe, które cechuje pewna materialność; mogą być osadzone na przykład w książkach (także podręcznikach), obrazach czy w dźwiękach.

W rozdziale wprowadzającym mowa jest także o złożoności gatunkowej podręcznika (compler genre), wynikającej głównie z różnorodności zamieszczanych tam tekstów oraz $z$ faktu, że są one narzędziem w uwarunkowanym wieloma czynnikami procesie nauczania.

${ }^{7}$ Autorka zaznacza, że nie uwzględnia języków nieeuropejskich, ponieważ nie zna dostatecznie dobrze języków z innych kontynentów, np. chińskiego czy arabskiego.

${ }^{8}$ Zdaniem autorki osoby młodsze nie uświadamiają sobie, że wiedza prezentowana w podręcznikach kształtowana jest przez różne punkty widzenia. 
Różnorodność elementów składowych podręcznika przekłada się także na mnogość sposobów prezentowania w nim zagadnień kulturowych. Duńska badaczka deklaruje, że analiza podręczników szkolnych zostanie przeprowadzona zgodnie z zasadami krytycznej analizy dyskursu (KAD) $w$ formie zaproponowanej przez Normana Fairclougha (por. np. WARzechA, 2014). Uściśla, że na poziomie tekstu najbardziej interesuje ją sposób przedstawienia kultury, społeczeństwa oraz świata, a także prezentowany w podręcznikach stosunek do wiedzy. Istotni są dla niej uczestnicy dyskursu: uczniowie, nauczyciele oraz autorzy podręczników, a także wydawcy (firmy wydawnicze). Analiza materiałów edukacyjnych jest, zdaniem autorki, sposobem ich interpretacji (odczytania) pod kątem obecności tematów kluczowych, za które uznaje: kwestie narodowościowe, edukację obywatelską, kwestie kulturowe, studia postkolonialne, ponadnarodowość. Tematy te mają być analizowane $w$ warstwie werbalnej oraz ikonicznej podręczników. Risager uznała, że omówienie podręcznika do nauki języka angielskiego pozwoli zilustrować wszystkie wymienione tematy kluczowe, natomiast podręczniki do nauki pozostałych języków przypisała wybranym przez siebie wątkom: podręcznik do nauki niemieckiego jest analizowany pod kątem narodowościowym, duńskiego - pod kątem edukacji obywatelskiej, francuskiego - kwestii kulturowych, hiszpańskiego - postkolonializmu, esperanto - kwestii ponadnarodowych. Autorka tłumaczy to względami praktycznymi: taki porządek analiz ograniczy objętość publikacji.

Rozdział 2. przynosi przegląd rozwiązań metodologicznych stosowanych do kulturoznawczo sprofilowanych analiz podręczników (za trzy najważniejsze uznaje się analizę tematyczną, analizę interkulturową oraz analizę typu „wiedza-władza” opartą na KAD), przegląd związanych z kulturą treści i obszarów uwzględnianych w nauczaniu języków obcych ${ }^{9}$ oraz przegląd 30 publikacji zawierających analizę kwestii kulturowych w podręcznikach szkolnych do nauki różnych języków obcych w zróżnicowany metodologicznie sposób.

Rozdziały 3-7 zawierają analizy kolejnych kwestii kluczowych. Mają one paralelną strukturę, co czyni tok wywodu klarownym i uporządkowanym. Każdy z nich zaczyna się od wprowadzenia informującego o sposobie rozumienia analizowanego tematu: autorka doprecyzowuje, jakie zagadnienia będą podlegały szczegółowej obserwacji. W rozdziale 3. (National Studies) uwaga poświęcona jest tzw. banalnemu nacjonalizmowi, politycznej i etnicznej koncepcji narodu; w rozdziale 4. (Citizenship Education Studies) poszukiwana jest odpowiedź na pytanie o to, w jaki sposób twórcy podręczników szkolnych starają się przygotować odbiorców do pełnienia funkcji obywateli; w rozdziale 5. (Cultural Studies) istotny jest termin lingwakultura, który podkreśla związki między językiem a kulturą („W lingwakulturze lingua dotyczy dyskursu, a nie jedynie słów i zdań. Kultura natomiast jest związana ze znaczeniami, które są w niej zawarte, i które wychodzą ponad to, co oferuje słownik i gramatyka" - ŻydeK-BEDNARCzUK, 2015: 83). W rozdziale 6. będącym studium postkolonialnym istotna jest kwestia dominacji państw kolonizujących nad kolonizowanymi i jej wpływ na kulturę. Rozdział 7. dotyczy kwestii ponadnarodowych, które autorka utożsamia między innymi z mówieniem o organizacjach ponadnarodowych (np. ONZ) oraz o globalizacji. Kolejne podrozdziały rozdziałów od 3. do 7. przynoszą obszerny przegląd

\footnotetext{
${ }^{9}$ Życie codzienne (np. żywienie), warunki życiowe, relacje międzyludzkie, wartości, wierzenia, stosunek do mniejszości religijnych i politycznych, język ciała, zasady życia społecznego (np. punktualność), zachowania rytualne (np. religia).
} 
literatury uwzględniającej tematy kluczowe (postkolonializm, narodowość, kwestie obywatelskie itd.). W końcowych częściach tych rozdziałów przeprowadzono analizę treści podręczników (oraz materiałów towarzyszących) na podstawie elementów KAD ze szczególnym uwzględnieniem: pozycjonowania i reprezentowania uczestników dyskursu; obrazu kultury, społeczeństwa i świata $w$ kolejno omawianych podręcznikach; stosunku do nauczania międzykulturowego. Autorka dołącza do analiz treściowych ilustracje stron z podręczników.

Praca kończy się obszernym rozdziałem podsumowującym, który (oprócz zaprezentowania najważniejszych wniosków płynących z analiz tematycznych) zawiera interesujące rozważania na temat kształcenia kompetencji międzykulturowej.

Lektura pracy Karen Risager wiązała się przede wszystkim z chęcią poszerzenia perspektywy oglądu zróżnicowanej grupy tekstów, jakimi są podręczniki do nauki języków obcych. Oczekiwania te zostały spełnione zwłaszcza dzięki bogatym odniesieniom bibliograficznym. Autorka powołuje się zarówno na opracowania starsze, będące źródłem określonych terminów lub sposobów analiz, jak i publikacje najnowsze. Poruszanie się po obszernej literaturze przedmiotu ułatwiają indeksy: rzeczowy i osobowy. Warto też zauważyć, że badaczka wybrała na przedmiot analiz podręczniki do nauki nie tylko języków nowożytnych, ale także języka narodowego nauczanego jako obcy oraz języka sztucznego, co jest rzadko spotykane na gruncie rodzimego piśmiennictwa.

Zastosowany sposób analiz materiału tekstowego nakazuje zachować pewien rodzaj czujności, wynikającej z faktu, że pracę Risager trudno jednoznacznie sklasyfikować: jest to publikacja językoznawcza, ale także dydaktyczna i kulturoznawcza. Najprościej chyba użyć określenia „interdyscyplinarna”, co czyni ją reprezentatywną dla współczesnego piśmiennictwa humanistycznego. Jeśli jednak chciałoby się tę książkę traktować jako źródło inspiracji dla analiz językoznawczych, problemem staje się fakt, że Risager pozostawia mechanizmy językowe na uboczu głównego nurtu swych obserwacji. Obrany sposób analiz przynosi wiele informacji na temat kontekstowych uwarunkowań funkcjonowania podręczników (historii danego kraju, sytuacji demograficznej, polityki edukacyjnej państwa) i są to kwestie opisane wyczerpująco. Autorka nie wskazuje jednak typowych konstrukcji językowych służących transmisji wiedzy, budowaniu stereotypów, wywierania wpływu itp. Jej obserwacje odnoszą się do treści poszczególnych fragmentów podręczników, ale bez ich cytowania (teksty widoczne są tylko na prezentowanych ilustracjach). Brak tekstowych egzemplifikacji sprawia, że stawiane tezy trudno weryfikować.

Z rozwagą należy także traktować kluczowy dla prowadzonych obserwacji termin reprezentacja. Bez wątpienia uczula on na występujące $w$ podręcznikach kwestie związane z ideologią i wpływami władzy, wydaje się jednak, że można go z powodzeniem zastąpić utrwalonym i obudowanym obfitą literaturą pojęciem językowego obrazu świata. W rozdziale 1. autorka posługuje się zresztą kilkukrotnie sformułowaniem image of the world, pisząc między innymi: „It does matter what image of the world the learning materials present to us as readers and users” [„Istotne jest, jaki obraz świata przedstawiają materiały edukacyjne swoim czytelnikom i użytkownikom"]. Wielość terminów i pojęć przytaczanych przez autorkę sprawia, że trudno czasami dostrzec, które z nich uważa za kluczowe, a które służą jej do zaprezentowania stanu wiedzy dotyczącego określonej kwestii szczegółowej. 
Podsumowując, praca Risager może zainteresować językoznawców zajmujących się analizą dyskursu edukacyjnego, dydaktyków, a także socjologów i kulturoznawców. Refleksja nad zaproponowanym przez badaczkę sposobem analiz materiałów do nauki języków obcych może zaowocować namysłem nad rolą, jaką nauczanie języków obcych odgrywa i odgrywało w życiu społecznym. W coraz bardziej zglobalizowanym świecie, w którym posługiwanie się językiem innym niż ojczysty staje się normą, refleksja taka wydaje się ze wszech miar pożądana.

\section{Literatura}

Czachur W., red., 2017: Lingwistyka kulturowa i międzykulturowa. Antologia. Warszawa.

Howatt A.P.R., 1984: A History of English Language Teaching. Oksford.

Kotlarska I., 2017a: Elementy ramy wydawniczej najstarszych polskich podręczników do nauki języka angielskiego jako źródło wiedzy o tekstach. W: Mitrenga B., red.: Linguarum Silva. T. 2: Problemy języka i tekstu w perspektywie historycznej i współczesnej. Katowice, s. 53-70.

Kotlarska I., 2017b: „Moje dziecię $w$ stanie twoim doskonałe języków posiadanie jest nieodbicie potrzebne": wstęp do charakterystyki gatunkowej dawnych polskich podręczników do nauki języków obcych nowożytnych (aspekt strukturalny). W: MARIAK L., RYchteR J., red.: Współczesny i dawny obraz dziecka w języku. Szczecin, s. 85-99.

Mıdunka W., 2018: Miejsce glottodydaktyki w językoznawstwie polonistycznym. "Język Polski" XCVIII, z. 2, s. 7-20.

Nocoń J., 2013: Dyskurs edukacyjny i jego społeczny zasięg. W: Nocoń J., TABısz A., red.: Język a Edukacja 2: Tekst edukacyjny. Opole, s. 13-26.

Przyklenk J., 2014: Więcej niż jeden - to dobrze czy źle? O stosunku Polaków do wielojęzyczności $w$ historii polszczyzny. W: Kuros-Kowalska K., Loewe I., red.: Dwujęzyczność, wielojęzyczność i wielokulturowość. Szanse i zagrożenia na drodze do porozumienia. Gliwice, s. 231-250.

PrzykLenk J., 2016: Kim jest mężczyzna w polskim nauczaniu języka angielskiego jako obcego? W: Mariak L., Rychter J., red.: Współczesny i dawny obraz mężczyzny $w$ języku. Szczecin, S. $187-195$.

Rejter A., 2018: Historyk języka jako tropiciel śladów. W: Hawrysz M., Uździcka M., red.: Zielonogórskie Seminaria Językoznawcze 2017: Wokół dziejów używania polszczyzny - wspólnoty, potrzeby, zachowania komunikatywne. Zielona Góra, s. 299-309.

Rittel T., 1998: Modelowanie dyskursu edukacyjnego. Kompetencja docelowa. W: Mrózek R., red.: Kultura. Język. Edukacja. T. 2. Katowice, s. 221-231.

RYPel A., 2012: Ideologiczny wymiar dyskursu edukacyjnego na przykładzie podręczników języka polskiego z lat 1918-2010. Bydgoszcz.

SıUсıак M., 2015: Znaczenie badań historycznojęzykowych dla interpretacji zjawisk współczesnej polszczyzny. „Poznańskie Studia Polonistyczne. Seria Językoznawcza” XXII, nr 1, s. 223-234.

Szymańska M., 2016: Między nauką o języku a rozwijaniem języka. Koncepcje kształcenia językowego na przełomie XX i XXI wieku. Kraków.

Warzecha A., 2014: Krytyczna analiza dyskursu (KAD) w ujęciu Normana Fairclougha. Zarys problematyki. „Konteksty Kultury” XI, z. 2, s. 164-189.

Żydek-Bednarczuk U., 2015: Spotkanie kultur. Komunikacja i edukacja międzykulturowa w glottodydaktyce. Katowice. 